\title{
Survey and analysis of flowers and ornamental plants at some nurseries in Ho Chi Minh City according to criteria for garden design
}

\author{
Tien T. M. Duong*, \& Thuy T. Vuong
}

Faculty of Environment and Natural Resources, Nong Lam University, Ho Chi Minh City, Vietnam

ARTICLE INFO
Research Paper
Received: November 20, 2019
Revised: March 13, 2020
Accepted: April 22, 2020
Keywords
Garden design
Ho Chi Minh City
Ornamental plant
Ornamental plant nursery
*Corresponding author
Duong Thi My Tien
Email: duongmytien@hcmuaf.edu.vn

\begin{abstract}
This research was carried out from October 2017 to October 2018 at some ornamental plant stores and nurseries in district 7, Go Vap district, district 10, Tan Binh district and Binh Chanh district. These are important ornamental plant trading and producing areas in Ho Chi Minh City. This study aimed to identify and analyse the potentials of using ornamental flowers, plants and trees for garden design. The investigation was conducted through questionnaire surveying, morphological comparison, species identification. The collected data was then statistically analysed. We divided these districts by zones and routes for the invesgation. There were 542 identified ornamental plant species in Ho Chi Minh City. According to the analysis of 7 important groups of ornamental plants such as tree trunks, shape of the tree, leaves, and flower groups, the bonsai pots for interior display, with large leaves, dark green to light green colors, large flowers, height from 0.1 to $1 \mathrm{~m}$ and no fragrance is common. Briefly, the obtained results would contribute to the design and construction of gardens in Ho Chi Minh City.
\end{abstract}

Cited as: Duong, T. T. M., \& Vuong, T. T. (2020). Survey and analysis of flowers and ornamental plants at some nurseries in Ho Chi Minh City according to criteria for garden design. The Journal of Agriculture and Development 19(2), 59-68. 


\title{
Khảo sát và phân tích hoa, cây cảnh tại một số vườn kiểng ở Thành phố Hồ Chí Minh theo các tiêu chí ứng dụng trong thiết kế sân vườn
}

\author{
Dương Thị Mỹ Tiên* \& Vương Thị Thủy \\ Khoa Môi Trường và Tài Nguyên, Trường Đại Học Nông Lâm TP.HCM, TP. Hồ Chí Minh
}

\section{THÔNG TIN BÀI BÁO}

Bài báo khoa học

Ngày nhận: 20/11/2019

Ngày chỉnh sửa: 13/03/2020

Ngày chấp nhận: 22/04/2020

Từ khóa

Cây cảnh

Thành phố Hồ Chí Minh

Thiết kế sân vườn

Vườn kiểng

*Tác giả liên hệ

Dương Thị Mỹ Tiên

Email: duongmytien@hcmuaf.edu.vn

\section{TÓM TẮT}

Nghiên cứu được thực hiện từ tháng 10/2017 đến tháng 10/2018 tại một số vườn kiểng kinh doanh hoa, cây cảnh tại khu vực quận 7, quận Gò Vấp, quận 10, quận Tân Bình, huyện Nhà Bè và huyện Bình Chánh, là các vùng buôn bán, sản xuất hoa, cây cảnh chính của TP. Hồ Chí Minh. Đề tài tập trung vào định danh và phân tích hoa, cây cảnh có tiềm năng trong thiết kế sân vườn. Đề tài được thực hiện bằng một số phương pháp như: bảng khảo sát, so sánh hình thái và định danh loài và phân tích, tổng hợp số liệu. Nhóm tác giả phân địa điểm khảo sát theo khu vực và các tuyến đường để điều tra. Kết quả đã định danh được 542 loài hoa, cây cảnh. Theo sự phân tích về 7 nhóm tiêu chí quan trọng về hình dáng hoa, cây cảnh như thân cây, hình dáng cây, lá, hoa, nhóm hoa, cây cảnh trồng chậu trưng bày nội thất, có lá lớn, màu sắc lá xanh đậm đến xanh nhạt, có hoa lớn, chiều cao từ $0,1 \mathrm{~m}$ đến 1 $\mathrm{m}$ và không có hương thơm là phổ biến. Kết quả nghiên cứu đóng góp vào thiết kế và thi công sân vườn tại TP. Hồ Chí Minh.

\section{1. Đắt Vấn Đề}

Cây là một vật liệu trong thiết kế cảnh quan (Hannebaum, 1998). Hình dạng, đường nét, chất cảm và màu sắc là đặc điểm nhận diện của cây độc lập hoặc nhóm cây (Robinson, 2004). Thiết kế dù đẹp đến đâu cũng vẫn tạo nên sự nhàm chán cho người thưởng thức nếu cứ trồng lặp lại các loại cây quen thuộc. Vì thế, việc bổ sung và du nhập các loài hoa, cây cảnh từ khắp nơi trên thế giới về Việt Nam nói chung và TP.HCM nói riêng là rất cần thiết. Tuy nhiên, hoa, cây cảnh được nhập vào thành phố với đủ chủng loại nhưng chưa xác định được tên khoa học chính xác, rất khó quản lý và nắm được đặc điểm, nguồn gốc, công dụng,... của chúng, gây khó khăn lớn cho việc nghiên cứu, sản xuất thương mại và ứng dụng trong thi công công trình.

Để định danh cây hoa cảnh, Tran (2012) đã cho thấy sự phong phú của ngành hạt trần trong "Tài nguyên cây cảnh Việt Nam" tập 1 và ngành hạt kín trong "Tài nguyên cây cảnh Việt Nam" tập 2 (Tran, 2016). Theo hướng thiết kế cảnh quan, Han (1996) đã chia cây xanh thành 2 nhóm: cây trang trí và cây bóng mát, trong khi đó Che (1997) lại chia cây xanh đô thị thành 8 nhóm chính dựa trên hình dạng và công dụng. Le \& Pham (1993) thì chia cây bóng mát thành 4 nhóm cây cây trang trí chia thành 9 nhóm.

Về cây cảnh ở TP.HCM, Tran (1998) phân loại cây xanh và cây cảnh Sài Gòn - TP.HCM thành 8 nhóm. Dinh (2000) đã điều tra được một dữ liệu lớn cây xanh đô thị nói chung (770 loài) ở TP.HCM.

Một số tài liệu nước ngoài như Lutsko \& ctv. (1989) đã phân loại cây xanh theo 2 nhóm tiêu chí: công dụng và hình dạng. Min \& ctv. (2003), đã điều tra và thống kê các loại cây xanh, hoa cảnh ở Singapore, trong đó, có một số loài đã được du nhập và trồng ở TP. Hồ Chí Minh như Mai thái (Xanthostemon chrysanthus (F.Muell.) Benth.), Liễu hồng (Rondeletia leucophylla), Bứa thái (Garcinia sp.), Bàng Đài Loan cẩm thạch (Terminalia mantaly 'tricolor'). Một tài liệu đáng 
chú ý về phân loại cây xanh ở khu vực các thành phố nhiệt đới là của Boo \& ctv. (2014), các tác phân loại gần 2.800 loài hoa, cây cảnh theo các nhóm như cây nội thất, cây hàng rào, cây chịu hạn, cây có hương thơm, dây leo, cây bóng mát, cỏ phủ nền, cây thủy sinh,...

\section{Vật Liệu và Phương Pháp Nghiên Cứu}

Điều tra được tiến hành tại một số vườn kiểng trên các tuyến đường thuộc 6 quận, huyện tập trung sản xuất và kinh doanh buôn bán hoa, cây cảnh của TP. Hồ Chí Minh, bao gồm: quận 7, quận Gò Vấp, quận 10, quận Tân Bình, huyện Nhà Bè và huyện Bình Chánh.

Thiết kế phiếu điều tra gồm các nội dung: Số hiệu phiếu, số hiệu ảnh, ngày điều tra, người điều tra, khu vực điều tra, vườn kiểng điều tra, địa chỉ, tên thương mại, danh pháp khoa học, họ thực vật, nguồn gốc, mô tả hình thái (thân, tán, lá; hoa, quả, hạt), nhóm công dụng, nhóm hình dạng, nhóm màu sắc hoa, nhóm màu sắc lá, nhóm màu sắc thân cây, kích thước lá, chiều cao cây, thời gian đạt chiều cao trưởng thành, đường kính tán, các đặc điểm nổi bật, đặc điểm sinh lý - sinh thái (nhu cầu nước, ánh sáng, ẩm độ, thời gian nở hoa, tốc độ sinh trưởng), ứng dụng trong sân vườn, duy tu và duy trì.

Đề tài sử dụng một số dụng cụ phục vụ công tác điều tra và lấy mẫu như máy ảnh, kéo, túi nilong (đựng mẫu), hộp nhựa, giấy báo, băng keo, thước và kẹp tiêu bản. Phương pháp điều tra là chụp ảnh, phỏng vấn các chủ vườn kiểng về nguồn gốc, tên thương mại, năm nhập và một số đặc điểm của hoa, cây cảnh. Sau đó, mô tả tại chỗ theo phiếu điều tra. Chụp ảnh từ tổng quát đến chi tiết các bộ phận hoa, quả, lá để phục vụ cho việc định danh các hoa, cây cảnh nhập nội mới. Sau đó tiến hành mã hóa số hiệu ảnh trong phiếu điều tra để thuận tiện trong việc nhận dạng và định danh. Cắt mẫu và cho vào túi nilong hoặc hộp nhựa đựng mẫu và ép mẫu bằng kẹp tiêu bản, rút khô ẩm độ bằng giấy báo, để nơi khô thoáng để làm mẫu vật nhanh khô, sau đó, thực hiện định danh loài. Việc định danh loài mới thực hiện bằng phương pháp hình thái so sánh: Dựa trên tài liệu tra cứu, các mô tả của phiếu điều tra, các hình ảnh chụp được, và mẫu tiêu bản tiến hành so sánh hình thái và cấu tạo bên ngoài của thực vật, so sánh các đặc điểm hình thái của cơ quan sinh dưỡng và cơ quan sinh sản giữa các cá thể với nhau.
Phương pháp tổng hợp số liệu: Dữ liệu sau khi thu thập, được tổng hợp trên phần mềm Microsoft Excel để phân tích, vẽ biểu đồ và thống kê.

\section{Kết Quả và Thảo Luận}

\subsection{Số lượng vườn kiểng}

Đề tài khảo sát tại 87 vườn kiểng thuộc 6 quận, huyện, trong đó, khu vực quận Gò Vấp và Tân Bình có 49 vườn, tiếp theo là khu vực quận 7 và huyện Nhà Bè với 22 vườn. Các quận Thủ Đức và quận 10 lần lượt điều tra trên 10 và 6 vườn kiểng. Các vườn kiểng được khảo sát ở 6 quận có phân bố tập trung để phát triển thành các khu chuyên kinh doanh cây cảnh, tạo điều kiện thuận lợi cho việc chọn mua cây cảnh của người dân.

\subsection{Số lượng loài và họ thực vật}

Đề tài đã khảo sát được 542 loài cây xanh và hoa kiểng thuộc 112 họ thực vật. Phân tích theo nhóm họ thực vật thấy rằng nhóm hoa, cây cảnh thuộc họ Ráy (Araceae) chiếm tỷ lệ cao nhất trên thị trường $(6,6 \%)$, các họ còn lại là họ Trúc đào (Apocynaceae) chiếm 5,5\%, họ Đậu (Fabaceae) chiếm 3,9\%, họ Thuốc bỏng (Crassulaceae) với tỷ lệ $3,7 \%$, các họ Cau dừa (Arecaceae) và Thầu dầu (Euphorbiaceae) là $3,5 \%$. Ngoài ra, các họ Cà phê (Rubiaceae), Cúc (Asteraceae), Ô rô (Acanthaceae), Phất dụ (Dracaenaceae), Xương rồng (Cactaceae), Sim (Myrtaceae), Dâu tằm (Moraceae), Loa kèn (Amaryllidaceae), Núc nác (Bignoniaceae) cũng là các họ có số lượng loài khá nhiều. Theo Hoang (1999), họ Ráy là họ phân bố chủ yếu ở vùng nhiệt đới và phù hợp với điều kiện TP. Hồ Chí Minh vốn thuộc vùng nhiệt đới gió mùa (theo phân loại Köppen, Geiger) có nhiệt độ trung bình hằng năm cao và hai mùa mưa, khô rõ ràng (EVN, 2014) làm tác động chi phối môi trường cảnh quan sâu sắc.

So sánh với Tran (1998) thì số lượng loài của đề tài khảo sát được đã vượt qua $(542 / 528)$. Điều này cho thấy do số lượng loài cây cảnh nhập nội đã tăng mạnh trong 20 năm qua và cũng như tác giả đã viết trong quyển sách này là chưa điều tra, định danh thống kê cây cỏ ở các nhà vườn. Thêm vào đó, việc khai thác các giống mới từ các loài cây rừng bản địa đẹp của Việt Nam cũng là nguyên nhân khiến số lượng loài có xu hướng tăng lên sau nhiều năm. Tuy nhiên, số lượng loài mà đề tài đã khảo sát cũng chưa tính đến một số 


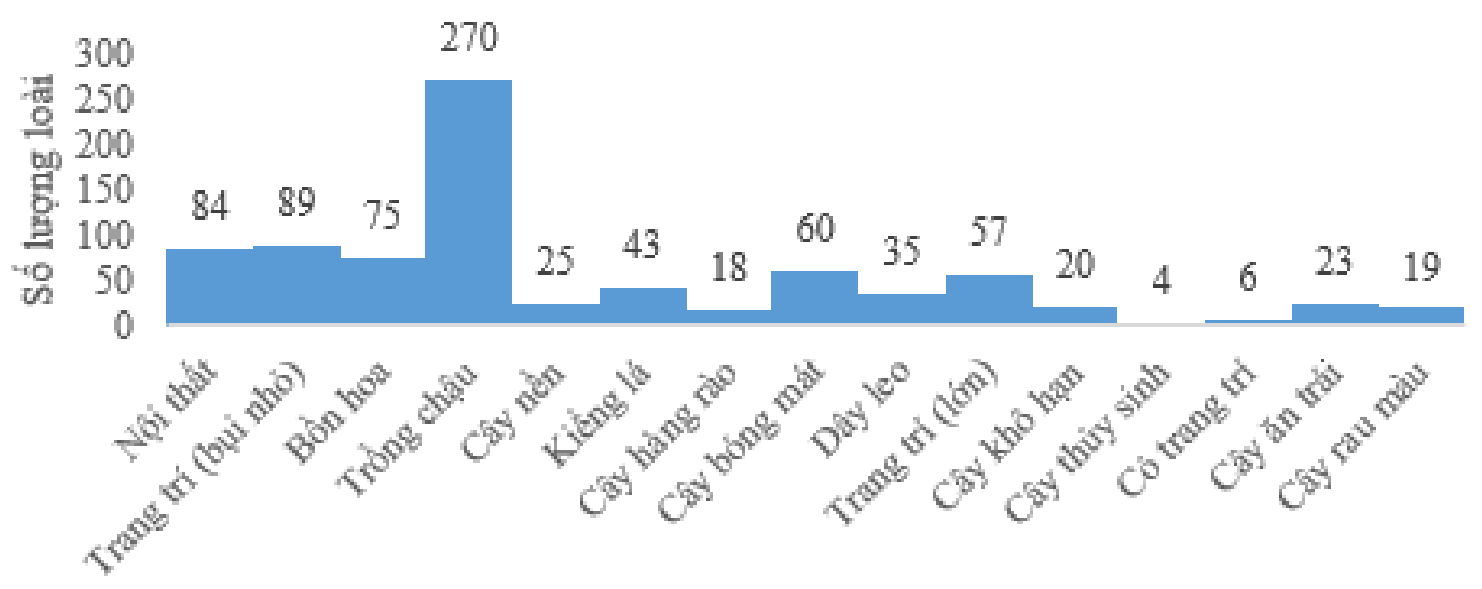

Công năng

Hình 1. Biểu đồ số lượng loài theo nhóm công dụng.

loài cây xanh, hoa kiểng trồng trên đường phố và công viên mà chỉ có vườn ườm của các xí nghiệp công trình đô thị nhân giống mà không thấy xuất hiện ở các nhà vườn và cửa hàng chuyên buôn bán cây xanh, hoa kiểng do giới hạn mục tiêu nghiên cứu của đề tài.

Trong thiết kế sân vườn và trang trí nội thất, ngoài hình dáng và kích thước của hoa, cây cảnh, các yếu tố như màu sắc thân, lá, hoa và kích thước lá, hoa, chiều cao cây, hương thơm hoa chi phối chính đến quyết định chọn loài cây bố trí. Thêm vào đó, tùy vào mục đích và nhu cầu trang trí, chủ nhà hoặc các nhà thiết kế có nhu cầu sử dụng các nhóm cây có công dụng khác nhau như dây leo giàn, cây trồng chậu trang trí làm điểm nhấn, cây trồng phủ nền, cây trồng thủy sinh trong hồ nước... Với mỗi phong cách thiết kế hoặc các góc trang trí khác nhau, người thiết kế sẽ dựa vào các tiêu chí trên để chọn loài hoa, cây cảnh phù hợp.

\subsection{Phân tích hoa, cây cảnh theo tiêu chí nhóm công dụng}

Dựa theo cách phân loại công năng của Boo \& ctv. (2014), Che (1997) và các yêu cầu trong nguyên tắc bố trí cây xanh sân vườn, chúng tôi chia cây xanh, hoa kiểng đã khảo sát được thành 15 nhóm công dụng (Hình 1). Các loài hoa, cây cảnh có thể được phân loại vào một hay nhiều nhóm khác nhau. Lý do của việc phân loại này là để người bố trí có thể dựa vào nhu cầu trang trí và mục đích trang trí để lựa chọn loài cho phù hợp. Theo đó, nhóm cây trồng chậu chiếm tỷ lệ cao nhất (hơn 50\%); thứ hai là nhóm cây bụi nhỏ để trang trí (16\%), nhóm cây nội thất $(15 \%)$ đứng thứ 3. Các nhóm cây thủy sinh, cây hàng rào và cỏ trang trí có số lượng loài là ít nhất.

Trong không gian nhà phố tại TP.HCM diện tích dành cho sân vườn chưa được chú trọng nhiều, các vị trí dành cho cây cảnh chủ yếu nhất là sân thượng, ban công, bồn hoa nhỏ trước nhà và giếng trời. Tại các văn phòng vị trí được ưa chuộng nhất là các góc phòng, tiếp đến là bàn làm việc hoặc gần cửa sổ. Vì vậy, cây trồng chậu và cây nội thất được chọn để linh hoạt trong bố trí và thay đổi. Ngoài ra, các vựa kiểng còn chú trọng nhập và buôn bán nhóm cây bưi trang trí có kích thước nhỏ chủ yếu để đáp ứng nhu cầu trồng cây hoa kiểng nhỏ ít chiếm diện tích và nhu cầu trang trí cây xanh công trình nhỏ như khuôn viên sân vườn nhà, quán café, nhà hàng.

\subsection{Phân tích hoa, cây cảnh theo hình dáng cây}

Để vẽ được hình dáng cây từ mức độ phác thảo đến chi tiết cũng như đặc tả phần lá đòi hỏi người thiết kế phải nắm vững đặc điểm hình dáng cây, lá (Bao, 2000). Theo tài liệu tham khảo về cách phân chia hình dáng cây của Che (1997) và căn cứ vào thực tế điều tra, nghiên cứu này chia hình dáng cây thành các nhóm: hình trứng, hình tháp, hình nấm, dạng cột, dạng thảm, dạng rũ, dạng bình hoa, hình cầu, hình chóp nón, dạng chổi và dạng quạt.

Nhóm cây dạng cầu chiếm tỉ lệ cao nhất (chiếm 


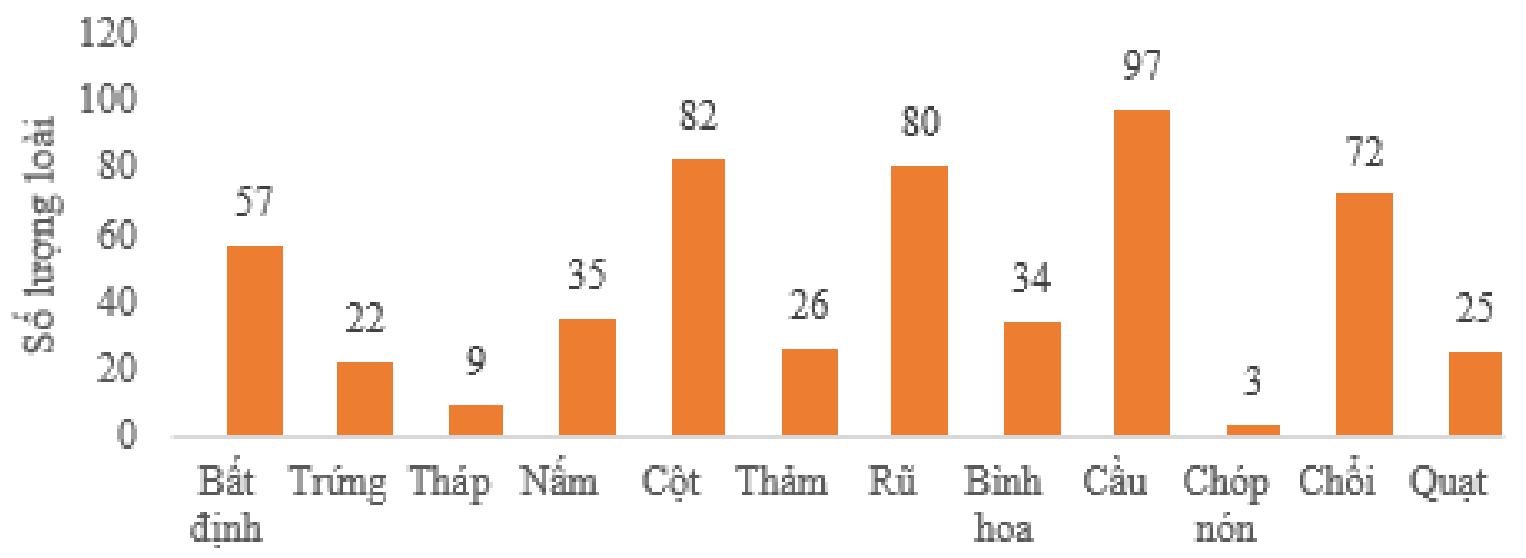

Hình dạng

Hình 2. Biểu đồ số lượng loài theo nhóm hình dáng cây.

tỷ lệ 18\%, Hình 2) cho thấy khả năng thu hút thị hiếu của người dân nhờ bề ngoài cây thể hiện sự viên mãn, may mắn. Nhóm cây dạng cầu đa số là cây trồng chậu và cây bụi trang trí thường được trồng hay bố trí ở tiền sảnh và tiểu cảnh sân vườn nhờ sự phối kết với cây khác hoặc trồng độc lập.

Nhóm cây dạng cột cũng rất phong phú về loài. Nhóm cây dạng cột chủ yếu là những loài thuộc họ phất dụ (Dracenaceae) có thân thẳng đẹp, vừa đáp ứng được nhu cầu thẩm mỹ vừa phù hợp với không gian nhỏ hẹp như các góc nhà, lối đi, hành lang. Vì vậy, nhóm cây dạng cột cũng chiếm đa số trong nhóm cây nột thất.

Nhóm cây dạng chổi cũng được ưa chuộng nhiều. Cây dạng chổi chủ yếu là cây thuộc nhóm nội thất với nhiều loài thuộc họ ráy (Araceae) có khả năng chịu bóng, dễ chăm sóc, hình dạng thuận lợi, dễ phối kết và rất thích hợp trong trồng cây vườn đứng.

Các nhóm cây thuộc những hình dạng còn lại chiếm tỉ lệ ít và không có đặc trưng riêng về họ hay nhóm công dụng chủ yếu nào. Tuy nhiên, hình dáng đặc biệt như dạng tháp, dạng chóp nón có số lượng ít nên hình dáng và loài cây thuộc nhóm này được xem là yếu tố độc đáo. Đây là yếu tố cần chú ý khi thiết kế để bố trí làm điểm nhấn.

\subsection{Phân tích hoa, cây cảnh theo màu sắc hoa}

Màu sắc được xem là một yếu tố thẩm mỹ ảnh hưởng đến sự lựa chọn và phối kết cây trồng (Robinson, 2004). Tran (1998) liệt kê 127 loài cây có hoa làm cảnh phổ biến và đẹp trên thị trường
TP. Hồ Chí Minh. Màu sắc hoa trong đề tài được phân chia theo Le \& Pham (1993). Qua điều tra tìm thấy được 388 loài có hoa (yếu tố hoa rõ ràng và được xem là một tiêu chí thẩm mỹ) chiếm $71,6 \%$ trong tổng số 542 loài điều tra được. Kết quả phân loại màu sắc hoa theo Hình 3 cho thấy:

Nhóm cây có hoa màu trắng chiếm tỷ lệ cao nhất $(31 \%)$. Hoa có màu trắng mang vẻ đẹp tinh khôi, tượng trưng cho sự trẻ trung và sang trọng. Nhóm màu nóng gồm: màu đỏ, vàng - cam và màu hồng có tổng tỉ lệ là $44 \%$, hoa có màu sắc sinh động, sặc sỡ mang lại vẻ đẹp hiện đại, tươi vui khi trang trí. Nhóm màu lạnh gồm: màu xanh và tím $11 \%$. Nhóm cây có hoa nhiều màu chiếm tỉ lệ $14 \%$. Màu sắc hoa đa dạng phong phú mang lại vẻ đẹp sinh động, nổi bật, nên dễ thu hút sự chú ý, vì vậy, cây cảnh có hoa nhiều màu rất được ưa chuộng cho trang trí, tạo điểm nhấn và sự bắt mắt trong cảnh quan sân vườn.

\subsection{Phân tích hoa, cây cảnh theo màu sắc lá}

Nếu hoa là yếu tố cây ấn tượng cho người thưởng ngoạn thì màu sắc lá cây sẽ là yếu tố kết hợp để làm nổi bật màu hoa hoặc là tiêu chí thẩm mỹ chính khi cây chưa ra hoa. Khi trang trí cây nội thất hoặc bố trí cây trang trí chịu bóng thì màu sắc lá là tiêu chí quan trọng bố trí hoa, cây cảnh. Ngoài nhóm cây có màu xanh lá phổ biến (hơn $79 \%$ ) thì một số cây có màu lá đặc biệt là xám, chẳng hạn Tuyết sơn phi hồ (Leucophyllum frutescens), Kè bạc (Bismarckia nobilis) và các loài xương rồng, sen đá 


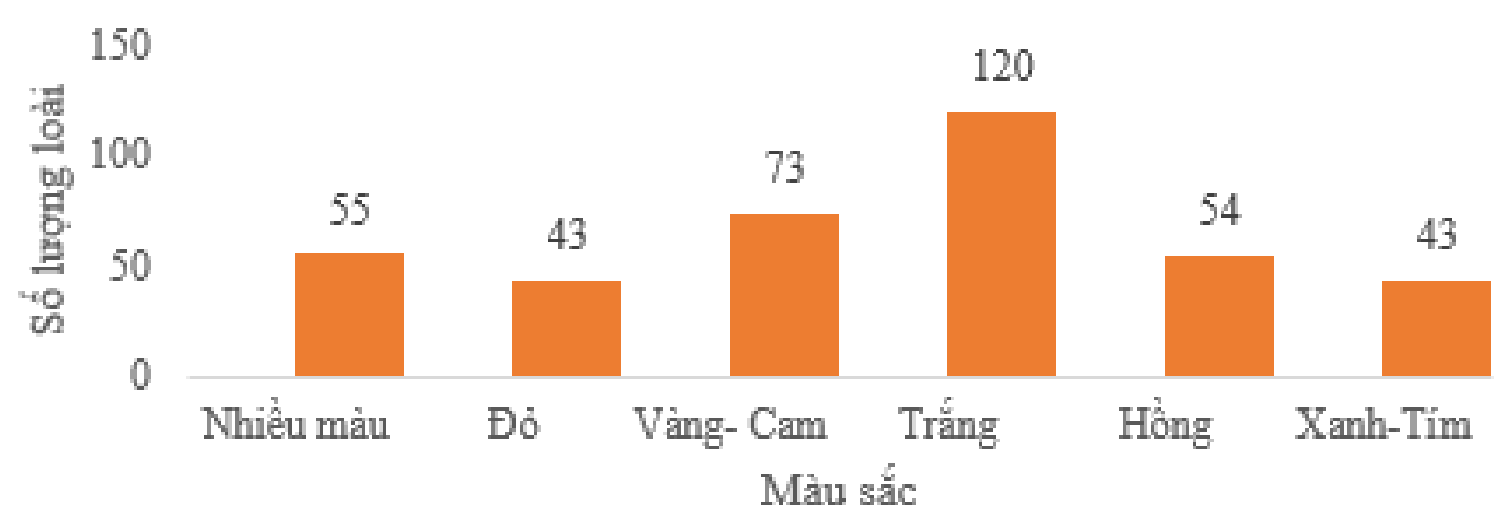

Hình 3. Biểu đồ số lượng loài theo nhóm màu sắc hoa.

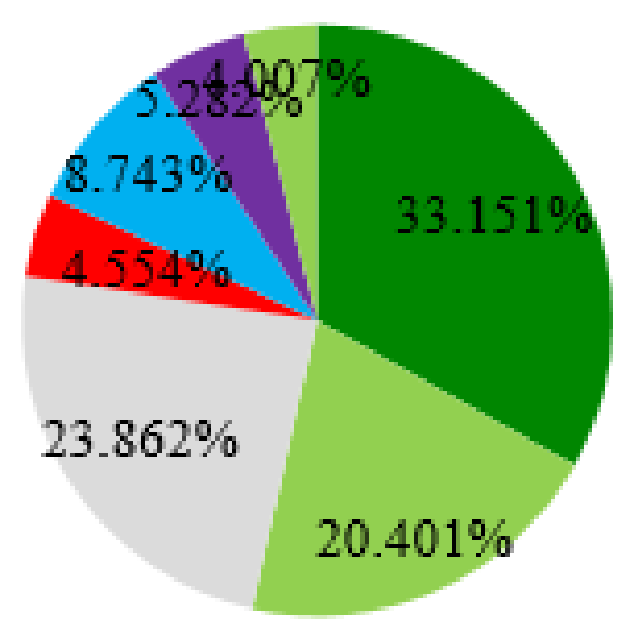

\section{- Xanh lá}

Xanh đậm

Xanh nhạt

- Xam

- Nhiều màu nớng

- Nhiều màu lạnh

- Màu 2 mặt khác biệt

Hình 4. Biểu đồ tỷ lệ thành phần loài theo nhóm màu sắc lá.

nhập nội như Xương rồng vân sơn (Cereus hidmannianus), Sen nhung (Echeveria pulvinata). Hoa, cây cảnh thuộc nhóm nhiều màu nóng là một số cây lá màu trang trí ngoại thất như Phất dụ tam sắc (Dracaena marginata 'Tricolor'), Tai tượng đỏ (Acalypha wilkesiana Müll.Arg.), Huyết dụ (Cordyline terminalis Kunth. var. ti Hort.) và một số loài chịu bóng có thể trang trí nội thất như Môn đốm (Caladium bicolor (Ait.) Vent.), Huy hoàng (Aglaonema nitidum tricolor (Jack.) Kunth.), Ngọc ngân (Aglaonema costatum f. foxii cultivar). Hoa, cây cảnh thuộc nhóm nhiều màu lạnh có thể kể đến như Lá khảm trắng (Fittonia argyroneura E. Coemans), Mạch môn sọc (Ophiopogon intermedius D.Don), Bàng Đài Loan cẩm thạch ( Terminalia mantaly 'tricolor'). Nhóm cây có màu lá hai mặt khác biệt có thể tăng sự lý thú cho người ngắm nhìn như Liễu hai da (Excocaria cochinchinensis Lour. var. cochinchinensis), Đuôi công (Calathea makoyana E. Morren), Thài lài tía (Tradescantia zebrina Hort. ex. Bosse.) (Hình $4)$.

\subsection{Phân tích hoa, cây cảnh theo kích thước lá}

Kích thước lá tác động đến kết cấu cây và là yếu tố quan trọng trong thiết kế sân vườn. Kích thước lá được chia theo các kích cỡ trên $7 \mathrm{~cm}$, từ 5 đến 7 $\mathrm{cm}$ và dưới $5 \mathrm{~cm}$. Theo Hình 5 , hoa, cây cảnh đã điều tra được đa phần $(58 \%)$ thuộc nhóm có kích thước lá lớn hơn $7 \mathrm{~cm}$, nhóm này thường thuộc 


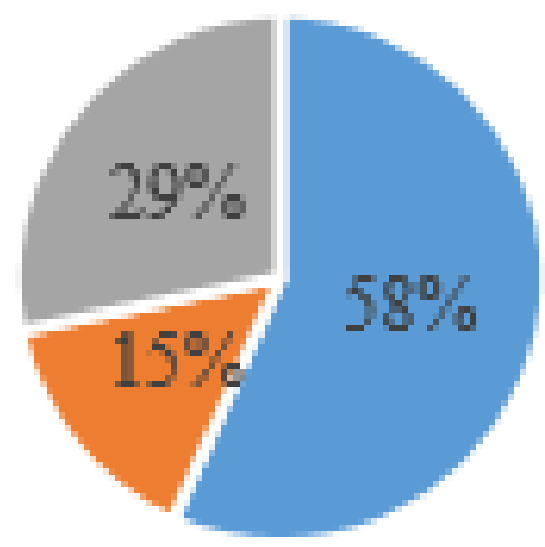

\section{- Lơn $(97 \mathrm{~cm})$ \\ - Nhỏ $(65 \mathrm{~cm})$}

- Trung bình (5-7cm)

Hình 5. Biểu đồ tỷ lệ thành phần loài theo nhóm kích thước lá.

họ Ráy (Araceae), họ Phất dụ (Dracenaceae) là những loài có màu lá tươi, bóng mướt, có nhiều màu đẹp thuộc nhóm cây nội thất được quan tâm lựa chọn nhiều cho nhu cầu thiết kế sân vườn đô thị. Nhóm cây có lá nhỏ dưới $5 \mathrm{~cm}$ chiểm tỷ lệ $29 \%$, phần lớn là nhóm cây trồng chậu và cây bụi trang trí. Với kích thước lá nhỏ người chơi cảnh được ưa chuộng trồng làm cây bonsai hoặc chậu cây mini để bàn.

\subsection{Phân tích hoa, cây cảnh theo màu sắc thân cây}

Đối với những cây bóng mát và cây có thân cây nổi bật của họ Cau dừa (Arecaceae) hoặc họ Phất dụ (Dracaenaceae) thì thân cây là đối tượng gây ấn tượng đầu tiên cho người thưởng ngoạn vì lá hoặc hoa lúc này đã vượt qua tầm mắt người nhìn.

Hình 6 cho thấy nhóm cây thân màu xanh lá có tỉ lệ cao nhất (43,4\%). Thân cây màu xanh thường có da bóng mướt mang lại vẻ tươi mới, trẻ trung phần lớn trong chúng là những loài thuộc họ Ráy (Araceae) được sử dụng làm cây nội thất văn phòng, cây trồng chậu, dây leo. Nhóm cây thân màu nâu có tỉ lệ cao thứ hai $(32,1 \%)$, chủ yếu thuộc nhóm cây trồng chậu, cây bụi trang trí, cây bóng mát và cây ăn trái và thuộc các họ Cà phê (Rubiaceae), Dâu tằm (Moraceae), Trúc đào (Apocynaceae), Núc nác (Bignoniaceae)... Nhóm cây thân màu xám cũng chiếm tỉ lệ cao (15,3\%) và phần lớn là cây bụi trang trí và cây trồng chậu. Họ phổ biến trong nhóm cây thân xám là Phất dụ (Dracenaceae), Trúc đào, Ráy và Dâu tằm.

\subsection{Phân tích hoa, cây cảnh theo chiều cao cây và đường kính tán cây}

Trừ 35 loài dây leo, hoa, cây cảnh còn lại được phân thành các cấp chiều cao như Hình 7 . Nhóm cây có chiều cao từ 0,1 m đến dưới 0,5 m (27\%), chiếm đa số là cây trồng chậu, nội thất và cây bụi trang trí nhỏ (nhóm công năng cây chiếm tỉ lệ cao đã phân tích ở trên). Mặt hạn chế về không gian ở đô thị làm xu hướng chọn lựa cây thấp nhỏ có phần ưu tiên mức chiều cao dưới $0,5 \mathrm{~m}$. Vì vậy, tỉ lệ cây ở nhóm có chiều cao từ 0,1 đến $0,5 \mathrm{~m}$ cao nhất. Nhóm cây có chiều cao từ $0,5 \mathrm{~m}$ đến dưới $1 \mathrm{~m}$ thì phần lớn vẫn là cây nội thất, cây trồng chậu và cây bụi nhỏ.

Nhóm cây có số lượng loài cao thứ 3 là từ 1 đến 1,5 m. Nhóm này đa phần gồm các cây bụi trang 


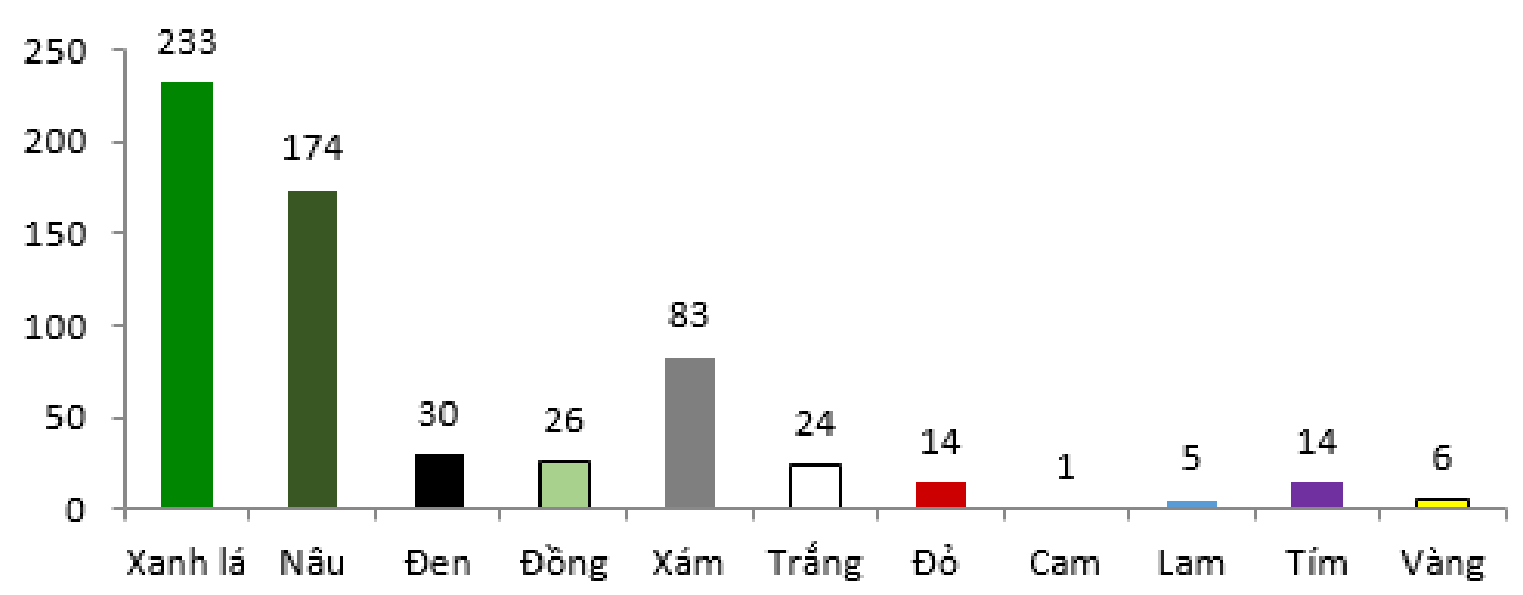

Hình 6. Biểu đồ số lượng loài theo nhóm màu sắc thân cây.
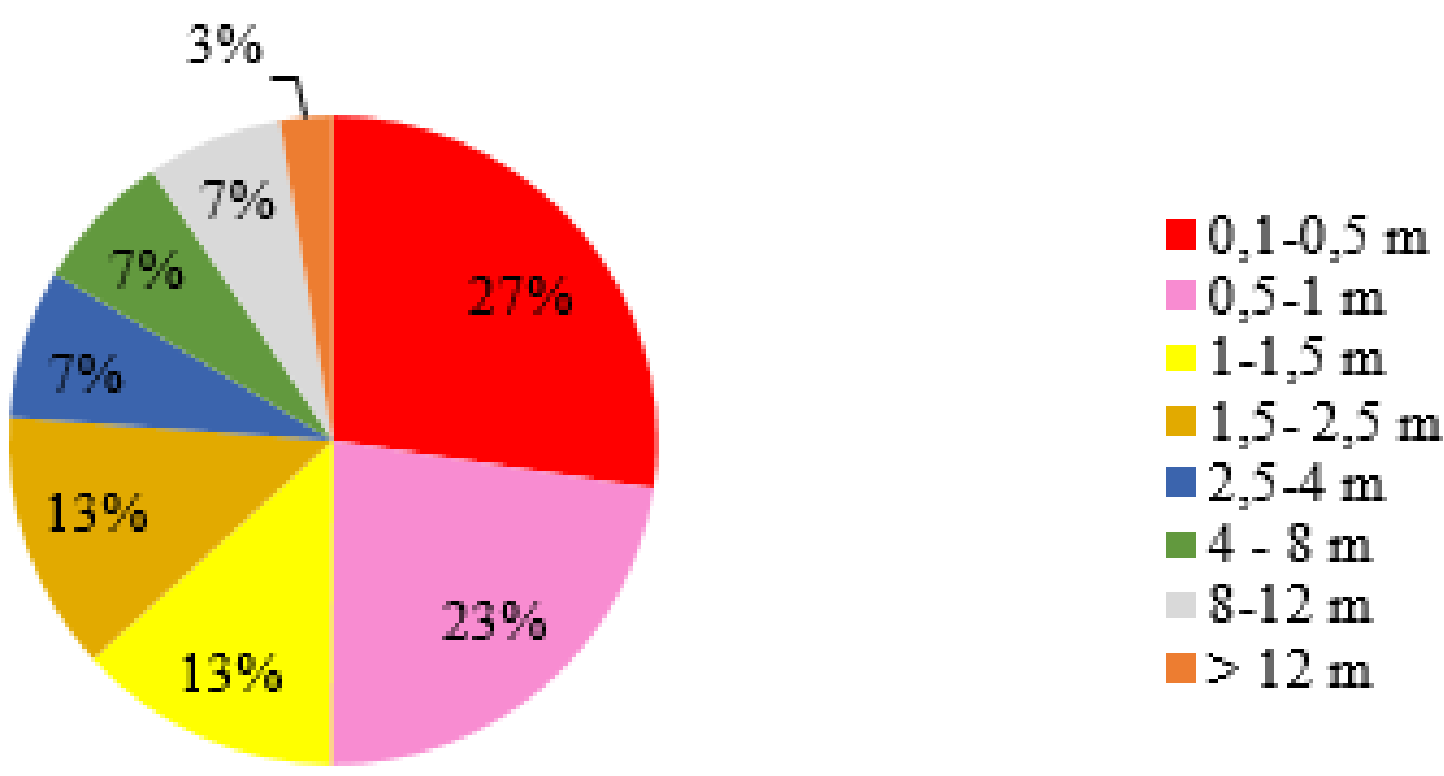

Hình 7. Biểu đồ tỷ lệ thành phần loài theo nhóm chiều cao cây.

trí lớn đang được buôn bán và một số cây trồng chậu lớn. Nhóm cây có số lượng loài ít nhất gồm các cây cao từ $8 \mathrm{~m}$ trở lên. Tỷ lệ các cây có chiều cao trên $8 \mathrm{~m}$ chiếm tỷ lệ ít là do các vựa kiểng ở TP. Hồ Chí Minh chủ yếu kinh doanh, bán lẻ cây và trung chuyển các cây bụi trang trí cho công trình.

Từ biểu đồ phân tích đường kính tán (Hình 8) cho thấy nhóm cây có đường kính tán từ $0,1 \mathrm{~m}$ đến dưới $0,5 \mathrm{~m}$ chiếm tỉ lệ rất cao là $33 \%$ tiếp đến là nhóm cây có đường kính tán từ $0,5 \mathrm{~m}$ đến $1 \mathrm{~m}$ chiếm $30 \%$, và tỉ lệ này cũng giảm dần về sau ở các mức đường kính tán rộng hơn. Điều này phù hợp với phân tích ở trên.

\subsection{Phân tích hoa, cây cảnh theo kích thước hoa, hương thơm hoa và mùa ra hoa}

Trong tổng số 388 loài có hoa thì nhóm cây có kích thước hoa từ $2 \mathrm{~cm}$ trở lên $(48,1 \%)$ mang giá trị thẩm mĩ cao, nổi bật và dễ trưng bày hơn so với cây hoa trung bình và nhỏ. Tỉ lệ loài có hoa lớn ở các nhóm cây họ Trúc đào (Apocynaceae), họ Núc Nác (Bignoniaceae), họ Loa kèn (Amarylli- 

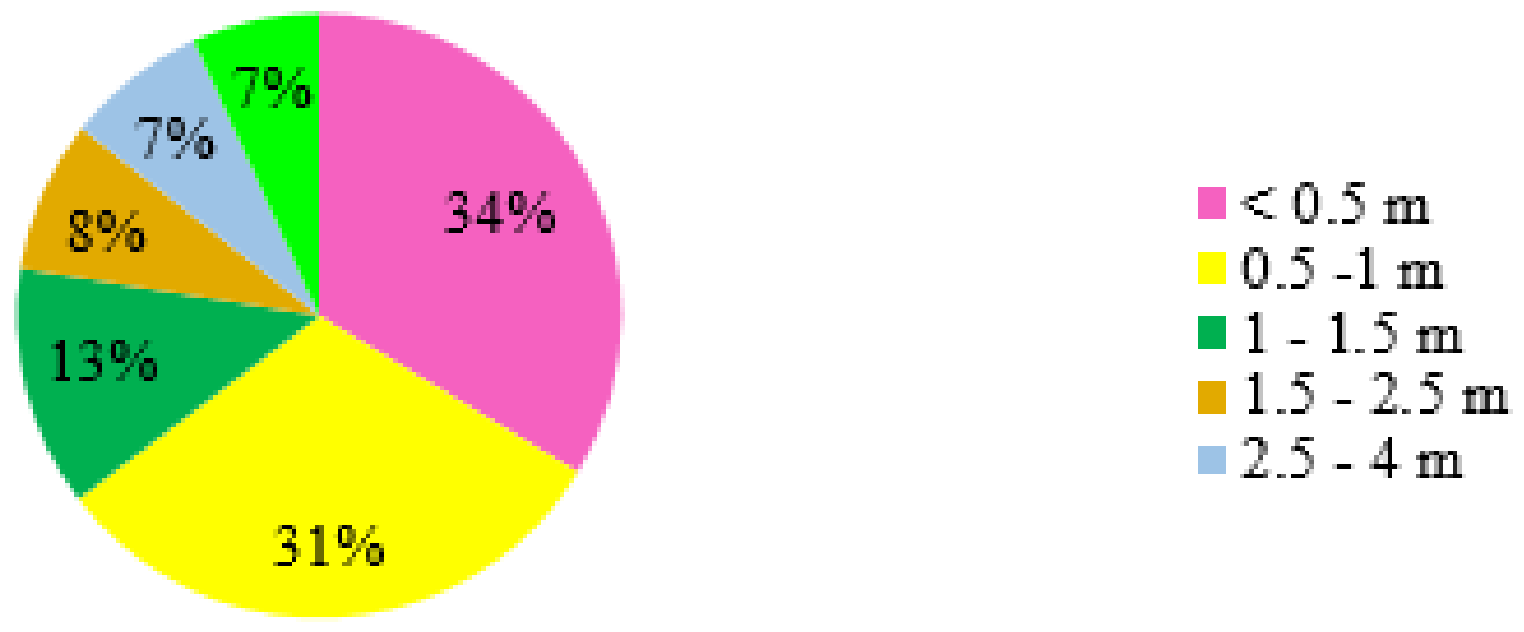

Hình 8. Biểu đồ tỷ lệ thành phần loài theo nhóm đường kính tán cây.

daceae), họ Đậu (Fabaceae), họ Cúc (Asteraceae) và họ Cà phê (Rubiaceae) được sử dụng để trang trí, trồng bồn hoa, dây leo và cây bóng mát luôn cao nhất. Trong khi đó, tỉ lệ cây có hoa nhỏ (19\%) chỉ chiếm nhiều ở nhóm cây bụi trang trí nhỏ, cây trồng chậu và cây cảnh trồng nền.

Cây có hương thơm góp phần nâng cao trải nghiệm của con người với cảnh quan (Harris \& Dines, 1998). Trong các loài cây có hoa đã khảo sát, nhóm cây không có mùi hương chiếm chủ yếu $(87 \%)$ vì nhóm này ít gây dị ứng về mùi. Nhóm cây bụi trang trí lớn, cây dây leo và cây trồng chậu là 3 nhóm có số lượng cây có hương thơm nhiều nhất. Nhóm hoa có thương thơm màu trắng được ghi nhận nhiều nhất, kế đến là nhóm hoa có màu vàng - cam. Nhóm hoa thơm thường là nhóm có đường kính hoa từ trung bình đến lớn (chiếm tỷ lệ nhiều nhất, 80\%).

Các loài nở hoa quanh năm được thị trường ưa chuộng nhiều hơn (72\%), chúng giúp cho khuôn viên của ngôi nhà luôn xinh tươii, tràn đầy sức sống, tháng 4 đến tháng 6 là giai đoạn có nhiều loài cây ra hoa nhất.

\section{Kết Luận}

Nghiên cứu đã điều tra được 542 loài hoa, cây cảnh thuộc 112 họ thực vật đang trưng bày và bán tại các vườn kiểng thuộc các quận, huyện đã khảo sát ở TP. Hồ Chí Minh. Nhận thấy, cây xanh, hoa kiểng đã khảo sát đa dạng về chủng loại và thành phần loài. Với đặc thù về không gian sống, không gian trưng bày, nhu cầu thẩm mỹ, nhóm hoa, cây cảnh trồng chậu trưng bày nội thất, có lá lớn, màu sắc lá xanh đậm đến xanh nhạt, có hoa lớn, có chiều cao từ $0,1 \mathrm{~m}$ đến $1 \mathrm{~m}$ và không có hương thơm chiếm tỷ lệ cao hơn. Các đặc tính khác của cây cũng đã được phân tích như mùa ra hoa, đường kính tán cây.

Cần có những nghiên cứu khảo sát rộng hơn về phạm vi điều tra về các cây cảnh không chỉ tại TP. Hồ Chí Minh mà còn tại các địa phương cung cấp các giống hoa, cây cảnh, đồng thời điều tra hiện trạng các loài hoa, cây cảnh đang được trồng và chăm sóc ở các đường phố, công viên và các vườn ươm thuộc các xí nghiệp công trình đô thị nhằm tạo dữ liệu phong phú cho thiết kế sân vườn.

\section{Lời Cảm Ơn}

Nghiên cứu này được hỗ trợ kinh phí bởi Trường Đại học Nông Lâm TP.HCM.

\section{Tài Liệu Tham Khảo (References)}

Bao, C. (2000). Techniques of urban landscape design. Ha Noi, Vietnam: Science and Technics Publishing House.

Boo, C. M., Chew, S. Y. J., \& Yong, J. W. H. (2014). Plant in tropical cities. Singapore: MMIZOO Publishing House.

Che, L. D. (1997). Trees - Development and management in urban environment. Ho Chi Minh, Vietnam: Agricultural Publishing House.

Dinh, D. Q. (2000). Research of collecting of urban trees data in Ho Chi Minh City. Ho Chi Minh City, Vietnam: MOET Office. 
EVN (Ho Chi Minh City Power Corporation). (2014). Vietnam: Ha Noi and Ho Chi Minh City power grid development sector project. Retrieved May 4, 2019 from, https://www.adb.org/sites/default/files/linkeddocuments/46391-001-ieeab-04.pdf.

Hannebaum, L. G. (1998). Landscape design - A practical approach. New Jersey, USA: Reston Publishing Company.

Han, N. T. (1996). Landscape architecture. Ha Noi, Vietnam: Construction Publishing House.

Harris, W. C., \& Dines, T. N. (1998). Time-saver standards for landscape architecture. New York, USA: McGraw-Hill, Inc.

Hoang, S. T. (1999). Classification of plants. Ha Noi, Vietnam: Education Publishing House.

Le, T. P., \& Pham, C. K. (1993). Urban plants. Ha Noi, Vietnam: Construction Publishing House.
Lutsko, J. R., \& Feller-Roth, B. (1989). Landscape plans (Ortho Library). California, USA: Ortho Books.

Min, B. C., Omar-Hor, K., \& Chow Lin, O. Y. (2003). 1001 Garden plants in Singapore. Singapore: Nation Parks Board.

Robinson, H. N. (2004). The Planting Design Handbook. Surrey, United Kingdom: Ashgate Publishing Limited.

Tran, H. (2016). Vietnam ornamental plants resources (Vol. 2). Ha Noi, Vietnam: Agricultural Publishing House.

Tran, H. (2012). Ornamental plants resources (Vol. 1). Ha Noi, Vietnam: Agricultural Publishing House.

Tran, H. (1998). Trees and ornamental plants in Sai Gon - Ho Chi Minh City. Ha Noi, Vietnam: Agricultural Publishing House. 